\title{
Patient preferences to value health outcomes in rheumatology clinical trials: Report from the OMERACT special interest group*
}

Citation for published version (APA):

Thomas, M., Fraenkel, L., Boonen, A., Bansback, N., Buchbinder, R., Marshall, D., Proulx, L., Voshaar, M., Richards, P., Richards, D. P., Hiligsmann, M., Guillemin, F., Shea, B., Tugwell, P., \& Hazlewood, G. (2021). Patient preferences to value health outcomes in rheumatology clinical trials: Report from the OMERACT special interest group*. Seminars in Arthritis and Rheumatism, 51(4), 919-924.

https://doi.org/10.1016/j.semarthrit.2021.05.008

Document status and date:

Published: 01/08/2021

DOI:

10.1016/j.semarthrit.2021.05.008

Document Version:

Publisher's PDF, also known as Version of record

Document license:

Taverne

Please check the document version of this publication:

- A submitted manuscript is the version of the article upon submission and before peer-review. There can be important differences between the submitted version and the official published version of record.

People interested in the research are advised to contact the author for the final version of the publication, or visit the DOI to the publisher's website.

- The final author version and the galley proof are versions of the publication after peer review.

- The final published version features the final layout of the paper including the volume, issue and page numbers.

Link to publication

\footnotetext{
General rights rights.

- You may freely distribute the URL identifying the publication in the public portal. please follow below link for the End User Agreement:

www.umlib.nl/taverne-license

Take down policy

If you believe that this document breaches copyright please contact us at:

repository@maastrichtuniversity.nl

providing details and we will investigate your claim.
}

Copyright and moral rights for the publications made accessible in the public portal are retained by the authors and/or other copyright owners and it is a condition of accessing publications that users recognise and abide by the legal requirements associated with these

- Users may download and print one copy of any publication from the public portal for the purpose of private study or research.

- You may not further distribute the material or use it for any profit-making activity or commercial gain

If the publication is distributed under the terms of Article 25fa of the Dutch Copyright Act, indicated by the "Taverne" license above, 


\title{
Patient preferences to value health outcomes in rheumatology clinical trials: Report from the OMERACT special interest group ix
}

\author{
Megan Thomas ${ }^{\mathrm{a}}$, Liana Fraenkel ${ }^{\mathrm{b}}$, Annelies Boonen $^{\mathrm{c}}$, Nick Bansback ${ }^{\mathrm{d}}$, Rachelle Buchbinder ${ }^{\mathrm{e}}$, \\ Deborah Marshall ${ }^{\mathrm{f}}$, Laurie Proulx ${ }^{\mathrm{g}}$, Marieke Voshaar ${ }^{\mathrm{h}}$, Pamela Richards ${ }^{\mathrm{i}}$, Dawn P. Richards ${ }^{\mathrm{g}, \mathrm{j}}$, \\ Mickael Hiligsmann ${ }^{\mathrm{k}}$, Francis Guillemin ${ }^{1}$, Beverly Shea ${ }^{\mathrm{m}}$, Peter Tugwell ${ }^{\mathrm{m}}$, Glen Hazlewood ${ }^{\mathrm{a}, \mathrm{f}, *}$ \\ ${ }^{a}$ Department of Community Health Sciences, University of Calgary, Calgary, Canada \\ ${ }^{\mathrm{b}}$ Yale University School of Medicine, Section of Rheumatology, CT, USA \\ ${ }^{\mathrm{c}}$ Department of Internal Medicine, Maastricht University Medical Center, Care and Public Health Research Institute, Maastricht, The Netherlands \\ ${ }^{\mathrm{d}}$ School of Population and Public Health, Faculty of Medicine, University of British Columbia, Vancouver, Canada \\ e Department of Epidemiology and Preventive Medicine, School of Public Health and Preventive Medicine, Monash University and Monash Department of Clinical \\ Epidemiology, Cabrini Institute, Melbourne, Australia \\ ${ }_{\mathrm{f}}^{\mathrm{f}}$ Department of Medicine, University of Calgary, Calgary, Canada \\ ${ }^{\mathrm{g}}$ Patient research partner, Canadian Arthritis Patient Alliance, Ottawa, Canada \\ ${ }^{\mathrm{h}}$ Patient research partner, Radboud University, Department of Pharmacy, Nijmegen, the Netherlands \\ i Patient research partner, University Hospitals, Bristol NHS Trust, Bristol, UK \\ ${ }^{\mathrm{j}}$ Patient research partner, Five02 Labs Inc., Toronto, Canada \\ ${ }^{\mathrm{k}}$ Department of Health Services Research, CAPHRI Care and Public Health Research Institute, Maastricht University, Maastricht, the Netherlands \\ ${ }^{1}$ Université de Lorraine, APEMAC, Nancy, France \\ ${ }^{\mathrm{m}}$ Department of Medicine, University of Ottawa, Ottawa, Canada
}

\section{A R T I C L E I N F O}

\section{Keywords:}

OMERACT

Patient preferences

Preference-based methods

Rheumatology

Clinical trials

Trade-offs

\begin{abstract}
A B S T R A C T
Objective: To inform a research plan for future studies by obtaining stakeholder input on the application of preference-based methods to clinical trial design.

Methods: We conducted a virtual OMERACT session to encourage stakeholder engagement. We developed materials for the session to facilitate discussion based on identified case examples and feedback sessions. Results: Participants prioritized incorporating patient preferences in all aspects of trial design with an emphasis on outcome selection. Participants highlighted the need for careful consideration around preference heterogeneity and equity factors.

Conclusion: Including patient preferences in trial design was considered a priority requiring further exploration to develop comprehensive guidance.
\end{abstract}

(C) 2021 Elsevier Inc. All rights reserved.

\section{Introduction}

Patients with rheumatic diseases face difficult trade-offs regarding their treatment to weigh the risks, benefits and costs of non-pharmacologic treatment, medications, and surgery [1-3]. Patients and their physicians should consider the available evidence on treatments and choose the most appropriate course of treatment in a shared decision-making context. To inform shared decision-making, it is important to generate appropriate evidence on outcomes that matter to patients.

\footnotetext{
*Guarantor of the article: Dr. Glen HazlewoodWriting Assistance: None

* Corresponding author at: Department of Medicine and Department of Community Health Sciences, University of Calgary, 3330 Hospital Drive NW, Calgary, ON, T2N 1N1, Canada.

E-mail address: gshazlew@ucalgary.ca (G. Hazlewood).
}

Broadly speaking, a preference is an expression of desirability of one alternative over another [4]. In a healthcare context, a patient can express a preference for alternative management options, or trade-offs related to healthcare decision making (e.g., risks, benefits). These preferences can be quantified using various methods, all of which seek to assign a value weight to the relevant trade-offs $[5,6]$. Direct utility-based approaches ask patients to choose between staying in a given heath state or gamble with a probability of immediately returning to full health with a chance of immediate death (standard gamble) or shortened life expectancy (time trade-off). With stated preference methods, such as a discrete choice experiment, patients are asked to choose, rate, or rank a set of alternatives [5]. These methods provide value weights for the trade-offs physicians and patients need to consider when making treatment decisions.

Preference-based methods are usually applied after evidence is generated, but there are critical decisions when designing clinical 
trials for which quantitative evaluation of patient preferences may lead to improvements in how evidence is generated. Issues such as determining which research questions should be addressed by trials, selecting which outcomes to measure, developing composite outcomes, and setting a minimum clinically important difference are some of the many decisions to be made that require assigning a value weight to outcomes or making trade-offs between different potential benefits and harms. Preference-based methods hold promise to inform these key decisions along the evidence continuum, including in the design of clinical trials.

\section{Patient preferences in rheumatology clinical trials (PPRCTs) in rheumatology steering committee}

Since its founding in 1992, OMERACT (Outcome Measures in Rheumatology) has transformed outcome measurement in rheumatology clinical trials [7-10]. Recognizing the potential of preferencebased methods, OMERACT established a Patient Preferences in Rheumatology Clinical Trials (PPRCTs) Special Interests Group (SIG) in 2019 composed of key stakeholders. Members of the steering committee of the PPRCTs SIG include 4 patient partners, 5 rheumatologists, and 6 researchers from around the world. Regular meetings have been conducted online via the Zoom platform to discuss objectives, create the research plan, review materials and to report progress.

This study was a first step from this SIG to assess the importance and feasibility of using patient preferences in clinical trial design. The aim of the study was to inform a research plan for future studies by obtaining stakeholder input on the application of preference-based methods to clinical trial design

\section{Materials and methods}

\section{Pre-meeting material}

We developed materials to familiarize potential SIG-participants on the topic to prepare for informed discussion at the live session. First, we collected case examples from panel members and through an informal literature search, to identify studies demonstrating different ways preference-based methods could be used to design clinical trials. Then, we conducted four 60 -minute sessions held one-onone with clinician researchers $(n=2)$ and patients $(n=2)$ via Zoom to refine the examples prior to conducting the stakeholder session. We used the identified case examples and feedback to develop an educational video discussing the concepts of patient preferences, preference-based methods, and how preference-based methods could be used in the design of clinical trials. The video was developed using the software VideoScribe, which provides a simple way to introduce complex material visually (video available at https://omeract.org/ working-groups/pprcts/). The development of the video went through three rounds of feedback, with input from patient partners, steering committee members, other patient-oriented research platforms, and content experts.

\section{Stakeholder meeting}

We conducted an OMERACT SIG session to facilitate stakeholder engagement and encourage discussion on the importance and feasibility of using preference-based methods in clinical trial design, including barriers and facilitators. Due to COVID-19, the SIG session was held virtually via Zoom on November 18, 2020. Participants were recruited via email through OMERACT's list of members as well as special invitation by SIG members. Participants watched the video beforehand.

During the session, we presented case examples along with our research plan, which was based on discussion with the steering committee, to receive input from participants. We engaged with participants by conducting polls to collect responses on importance and areas of priority. As an example of the diversity of preferences, we asked participants to complete a simplified stated preference and standard gamble exercise (Appendix). Open discussion was held, and the chat feature of Zoom was used for participants to ask questions, share comments and to interact with one another.

We conducted descriptive analyses on the poll results to identify measures of frequency to inform future work. The feedback session recordings were analyzed to identify prompts for discussion in the session. The Zoom chat transcript was reviewed to identify key considerations and areas of concern. We followed the GRIPP short form when reporting the study [11].

\section{Results}

\section{Pre-meeting material}

We prepared 3 case examples to guide our session, which were selected based on their application to outcome measurement in trials, which aligns with OMERACT's mission (Table 1). The examples were also used to inform the feedback sessions, where participants were asked to consider the use of preference-based methods in clinical trial design (Table 2). The case examples and feedback sessions allowed us to identify important concepts to include in the video to explicitly outline how preferences can be elicited, and moreover how they can be applied to clinical trial design.

\section{Stakeholder meeting}

The one-hour SIG session included 49 attendees [19 patient research partners, 29 researchers and clinicians, and 1 policymaker (recording available at https://omeract.org/working-groups/pprcts/).

\section{Priority-setting}

There were many considerations brought up in the discussion portion of the session. Participants were asked to rate how important they felt this topic was to pursue (Table 3). When asked what areas this SIG should prioritize, most participants voted that All aspects of trial design ( $n=24,58.5 \%$ ) were important to consider, with Outcome selection/prioritization ( $n=9,22.0 \%$ ), being the next highest option (Table 3). Overall, this spoke to the role of patient preferences along the continuum of trial design.

\section{Feasibility, key considerations, and challenges of including patient preferences in trial design}

Participants stated challenges in ensuring appropriate sampling and aggregation of preferences of different patients. Participants also discussed the importance of considering how clinical factors such as duration of disease, current level of disease activity and symptom burden, treatment experience and comorbidities may influence preferences. To address this challenge, participants identified that preference-based methods must acknowledge and measure preference heterogeneity. As an illustration of preference heterogeneity, SIG participant responses in the stated preference and standard gamble exercises during the meeting were divided; in the stated preference exercise $56.4 \%$ chose the treatment with the higher chance of benefit but with higher side effects. In the standard gamble, $52.6 \%$ chose to take the treatment, rather than remain in their current health state (Appendix). Following these exercises, participants identified that patients must be adequately informed about their choices to express a preference.

Several links between preferences, equity considerations, and shared decision-making were discussed. Socioeconomic and cultural factors were also acknowledged as important issues to consider in the context of clinical trial design. Participants noted that preferences 
Table 1

Case examples.

\section{Prioritizing outcomes}

To understand whether a drug (or other intervention) is effective in a clinical trial, we first need to define which outcomes to measure and how to define them. Often, these outcomes are selected and defined by researchers, but there is an opportunity to include patient preferences in this process. For example, in one study researchers chose to measure the outcome of adverse events (any undesirable experience associated with the use of a treatment in a patient) and used patient preferences to define what an adverse event was. The researchers grouped adverse events of similar importance to patients, which could improve the way adverse events are collected and reported in trials [12]. This allowed the researchers to compare patients' overall experiences on one treatment versus another. With this information, the researchers were able to add number values to compare patients' overall experiences on different medications. Using patient preferences to define an outcome could help provide patients and their doctors with a better understanding of the range and likelihood of the total effects of competing treatment options on their quality of life.

\section{Developing a composite outcome}

Composite outcomes (when multiple endpoints are combined) are common in rheumatology. Often when researchers develop composite outcomes, they apply equal "weights" to the different parts of the outcome, meaning that each part of the outcome are considered equally in the results. However, patient preferences may help inform these decisions, and could be included to help choose the various weights applied to different parts of the outcome. For example, in one study, the researchers used a preference-based method to inform the weights of the parts of a composite outcome for cardiovascular trials [13]. In this example, the patients did not assign equal weights to each part of the composite outcome being measured. Instead, it was found that risk of death was most important, followed by stroke, potential increased longevity and recovery time, myocardial infarction, and risk of repeat revascularization. The researchers found that using a preference-weighted outcome compared with assigning equal weights to each component would affect how the results of a clinical trial were interpreted, and ultimately, decision-making for cardiovascular treatments.

Defining minimally important differences in outcomes and setting noninferiority margins

Powering a trial is the probability of finding a difference between study groups when a true difference exists. To power a trial requires knowing what an important difference (the smallest change in a treatment outcome that patients would identify as important) in the outcome is. For example, consider when patients with rheumatoid arthritis and their doctors are trying to reduce treatment. One consequence of this is that some patients may have a flare (episodes of increased disease activity during which people's arthritis symptoms are more severe). If this happens infrequently, people may decide that the benefits of reducing their meds (lower cost, less side effects, etc.) outweigh this increased risk of flares. Deciding what "infrequently" means is challenging. In a recent randomized trial of treatment reduction in rheumatoid arthritis, researchers chose a $20 \%$ increase in flare as their primary outcome when selecting their non-inferiority margin, because "in [their] clinical view, this number seems to balance well with an expected chance of being able to reduce the dose or stop the drug of about $60 \%$ and $15 \%$ respectively" [14]. However, it is not clear to what extent this reflects patient preferences. Patient preference methods could provide a tool to inform these decisions through the eyes of patients, rather than physicians or researchers.
Table 2

Participant quotes from feedback sessions.

\begin{tabular}{ll}
\hline Stakeholder category & Participant quotes \\
\hline Clinician researchers & "It makes complete sense why patients might choose \\
& differently than physicians; we worry about differ- \\
& ent things. We might value similar things, we \\
& might all want the best benefit, but we certainly are \\
& going to have different risk tolerances for side \\
& effects." \\
& "I think the work you are doing is very important, \\
& that you say, 'okay we are going to look at the \\
& whole spectrum of the clinical trial or clinical study' \\
& [...] we can start solving problems with preferen- \\
& ces if we can prioritize where they are most \\
& important." \\
& "If we can design things from the beginning to incor- \\
& porate those preferences on a broader scale, then \\
& when it comes down to the individual level \\
& patients hopefully won't need to fight in the same \\
& way to get something that fits them and their life." \\
"To me it's like when I do get a choice, because I & don't often get a choice as a patient, it is where \\
& there are specific opportunities or options available \\
& that I can say 'no I prefer X over Y' [...] that repre- \\
& sents something I value on a personal level."
\end{tabular}

are commonly shaped by peoples' lived experiences and thus warrant careful consideration. To recognize the importance of equity, it was suggested that we collaborate with Working Groups within OMERACT, specifically the Equity group. It was recognized that patient preferences are also well-aligned with shared decision-making, as part of the downstream impact of including preferences in clinical trial design, which presents an opportunity to collaborate with the Shared Decision-Making group.

\section{Discussion}

International stakeholders provided feedback at the OMERACT session which will inform this SIG's research plan. Participants confirmed the importance of the topic, as well as identified key considerations and challenges. The importance of ensuring representation of diverse patient preferences was emphasized, with participants identifying that socioeconomic and cultural factors need to be considered when eliciting preferences for trial design, as they could impact outcome evaluation. Based on poll results, we will prioritize developing guidance on incorporating patient preferences for the incorporation of patient preferences in all aspects of trial design.

Strengths of this work include the provision of international perspectives from patients, clinicians, and researchers to guide our research. We are beginning the journey to finding novel approaches to integrate preferences into clinical trials. This work complements

Table 3

Poll Results .

\begin{tabular}{|c|c|c|c|}
\hline Poll Question & Poll Options & Frequency (n) & Percentage (\%) \\
\hline \multirow[t]{5}{*}{ Please rate how important you feel this topic is to OMERACT: } & Very important & 25 & 60.0 \\
\hline & Important & 13 & 31.0 \\
\hline & Unimportant & 0 & 0 \\
\hline & Very unimportant & 1 & 2.4 \\
\hline & Not sure & 1 & 2.4 \\
\hline \multirow{4}{*}{$\begin{array}{l}\text { Which of the following areas do you think our group should } \\
\text { focus on? (highest priority within OMERACT) }\end{array}$} & Outcome selection/prioritization & 9 & 22.0 \\
\hline & Selecting interventions & 1 & 2.4 \\
\hline & All aspects of trial design & 24 & 58.5 \\
\hline & Other (type in chat) & 1 & 2.4 \\
\hline
\end{tabular}


existing efforts to include patient preferences during the drug development life cycle $[15,16]$.

Next steps will involve conducting a formal scoping review to consider how preference-based methods have been applied to clinical trial design. We will then conduct semi-structured interviews with patients, clinicians, and researchers for in-depth exploration on the feasibility of using preference-based methods in trial design. We anticipate collaboration with OMERACT Working Groups to provide worked examples of applying preference-based methods within outcome development and trial design. This work will inform future guidance on approaches for considering patient preferences within clinical trials.

\section{Author contributions}

\begin{tabular}{|c|c|c|}
\hline Author & Affiliation & CRediT author statement \\
\hline Megan Thomas & $\begin{array}{l}\text { Department of Community } \\
\text { Health Sciences, Univer- } \\
\text { sity of Calgary, Alberta, } \\
\text { Canada }\end{array}$ & $\begin{array}{l}\text { Conceptualization; Investi- } \\
\text { gation; Visualization; } \\
\text { Writing - Original Draft }\end{array}$ \\
\hline Liana Fraenkel & $\begin{array}{l}\text { Yale University School of } \\
\text { Medicine, Section of Rheu- } \\
\text { matology, Connecticut, } \\
\text { USA }\end{array}$ & $\begin{array}{l}\text { Conceptualization; Resour- } \\
\text { ces; Writing - Review \& } \\
\text { Editing }\end{array}$ \\
\hline $\begin{array}{l}\text { Annelies } \\
\text { Boonen }\end{array}$ & $\begin{array}{l}\text { Department of Internal Med- } \\
\text { icine, Maastricht Univer- } \\
\text { sity Medical Center, Care } \\
\text { and Public Health } \\
\text { Research Institute, Maas- } \\
\text { tricht, The Netherlands }\end{array}$ & $\begin{array}{l}\text { Conceptualization; Resour- } \\
\text { ces; Writing - Review \& } \\
\text { Editing }\end{array}$ \\
\hline Nick Bansback & $\begin{array}{l}\text { School of Population and } \\
\text { Public Health, Faculty of } \\
\text { Medicine, University of } \\
\text { British Columbia, Vancou- } \\
\text { ver, Canada }\end{array}$ & $\begin{array}{l}\text { Conceptualization; Writing - } \\
\text { Review \& Editing }\end{array}$ \\
\hline $\begin{array}{l}\text { Rachelle } \\
\text { Buchbinder }\end{array}$ & $\begin{array}{l}\text { Department of Epidemiology } \\
\text { and Preventive Medicine, } \\
\text { School of Public Health } \\
\text { and Preventive Medicine, } \\
\text { Monash University and } \\
\text { Monash Department of } \\
\text { Clinical Epidemiology, } \\
\text { Cabrini Institute, Mel- } \\
\text { bourne, Australia }\end{array}$ & $\begin{array}{l}\text { Conceptualization; Writing - } \\
\text { Review \& Editing }\end{array}$ \\
\hline
\end{tabular}

(continued)

\begin{tabular}{|c|c|c|}
\hline $\begin{array}{l}\text { Deborah } \\
\text { Marshall }\end{array}$ & $\begin{array}{l}\text { Department of Medicine, } \\
\text { University of Calgary, Cal- } \\
\text { gary, Canada }\end{array}$ & $\begin{array}{l}\text { Conceptualization; Writing - } \\
\text { Review \& Editing }\end{array}$ \\
\hline Laurie Proulx & $\begin{array}{l}\text { Canadian Arthritis Patient } \\
\text { Alliance, Ottawa, Canada }\end{array}$ & $\begin{array}{l}\text { Conceptualization; Resour- } \\
\text { ces; Writing - Review \& } \\
\text { Editing }\end{array}$ \\
\hline $\begin{array}{l}\text { Marieke } \\
\text { Voshaar }\end{array}$ & $\begin{array}{l}\text { Radboud University, Depart- } \\
\text { ment of Pharmacy, Nijme- } \\
\text { gen, the Netherlands }\end{array}$ & $\begin{array}{l}\text { Conceptualization; Resour- } \\
\text { ces; Writing - Review \& } \\
\text { Editing }\end{array}$ \\
\hline Pamela Richards & $\begin{array}{l}\text { University Hospitals, Bristol } \\
\text { NHS Trust, Bristol, UK }\end{array}$ & $\begin{array}{l}\text { Conceptualization; Writing - } \\
\text { Review \& Editing }\end{array}$ \\
\hline $\begin{array}{l}\text { Dawn P } \\
\text { Richards }\end{array}$ & $\begin{array}{l}\text { Canadian Arthritis Patient } \\
\text { Alliance, Toronto, Canada; } \\
\text { Five02 Labs Inc., Toronto, } \\
\text { Canada }\end{array}$ & $\begin{array}{l}\text { Conceptualization; Writing - } \\
\text { Review \& Editing }\end{array}$ \\
\hline $\begin{array}{l}\text { Mickael } \\
\text { Hiligsmann }\end{array}$ & $\begin{array}{l}\text { Department of Health Serv- } \\
\text { ices Research, CAPHRI } \\
\text { Care and Public Health } \\
\text { Research Institute, Maas- } \\
\text { tricht University, Maas- } \\
\text { tricht, the Netherlands }\end{array}$ & $\begin{array}{l}\text { Conceptualization; Writing - } \\
\text { Review \& Editing }\end{array}$ \\
\hline $\begin{array}{l}\text { Francis } \\
\text { Guillemin }\end{array}$ & $\begin{array}{l}\text { Rheumatic Diseases, Univer- } \\
\text { sity of Lorraine, Nancy, } \\
\text { France }\end{array}$ & $\begin{array}{l}\text { Conceptualization; Writing - } \\
\text { Review \& Editing }\end{array}$ \\
\hline Beverly Shea & $\begin{array}{l}\text { Department of Medicine, } \\
\text { University of Ottawa, } \\
\text { Ottawa, Canada }\end{array}$ & $\begin{array}{l}\text { Conceptualization; Project } \\
\text { administration }\end{array}$ \\
\hline Peter Tugwell & $\begin{array}{l}\text { Department of Medicine, } \\
\text { University of Ottawa, } \\
\text { Ottawa, Canada }\end{array}$ & $\begin{array}{l}\text { Conceptualization; } \\
\text { Supervision }\end{array}$ \\
\hline Glen Hazlewood & $\begin{array}{l}\text { Department of Community } \\
\text { Health Sciences, Univer- } \\
\text { sity of Calgary, Alberta, } \\
\text { Canada; Department of } \\
\text { Medicine, University of } \\
\text { Calgary, Calgary, Canada }\end{array}$ & $\begin{array}{l}\text { Conceptualization; Investi- } \\
\text { gation; Visualization; } \\
\text { Writing - Original Draft; } \\
\text { Supervision }\end{array}$ \\
\hline
\end{tabular}

\section{Financial support}

Dr. Hazlewood is supported by a Canadian Institutes of Health Research New Investigator Award. This work was supported by a grant from the Canadian Institutes of Health Research (CIHR) [FRN 147,822]. Dr. Deborah Marshall receives salary support from Arthur J. E. Child Chair in Rheumatology Research.

\section{Acknowledgements}

The authors wish to express their gratitude to the OMERACT administrative and leadership team, and to all participants of the OMERACT session. 


\section{Appendix}

Figs. 1 and 2

\begin{tabular}{|c|c|c|}
\hline Treatment property & Treatment A & Treatment B \\
\hline How you take the medications & Daily pills & Weekly injections \\
\hline $\begin{array}{l}\text { Probability of a major symptom } \\
\text { improvement }\end{array}$ & $40 \%$ & $60 \%$ \\
\hline $\begin{array}{l}\text { Probability of having a side effect that } \\
\text { requires you to stop the medication }\end{array}$ & $10 \%$ & $20 \%$ \\
\hline Need to limit alcohol & No & Yes \\
\hline
\end{tabular}

Fig. 1. Example of DCE:

We provided two treatment options for participants to consider. Treatment A was a daily pill with a $40 \%$ probability of a major symptom improvement, $10 \%$ probability of having a major side effect, and no need to limit alcohol consumption. Treatment B consisted of weekly in injections with a $60 \%$ probability of a major symptom improvement, $20 \%$ probability of having a major side effect, and a need to limit alcohol consumption. Of the 39 participants who responded, the majority $(n=22,56.4 \%)$ chose to take Treatment B.

\section{Standard Gamble-Direct Elicitation}

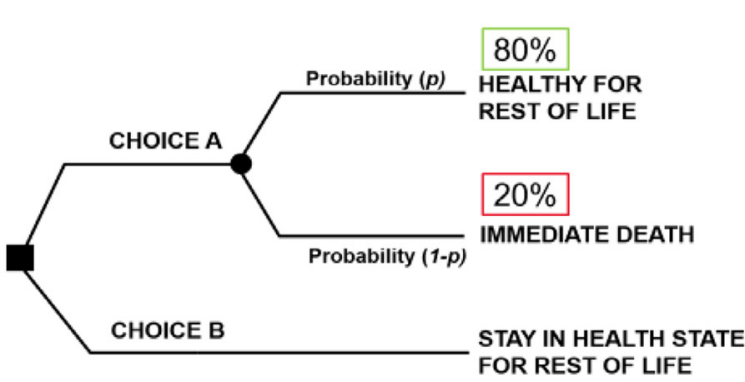

- Severe RA and problems

with:

- Walking

- Self-care

- Daily activities

- Leisure activities

- Anxiety and/or depression

- Extreme pain and discomfort

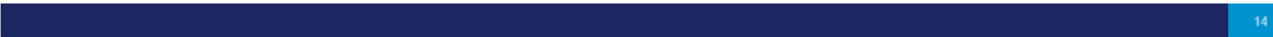

\section{POLL}

- Which would you choose?

a) Take the treatment ( $80 \%$ chance of returning to full health, $20 \%$ chance of immediate death)

b) Remain in current health state

Fig. 2. Example of standard gamble:

We provided a current health state for participants to consider. Participants were told to consider having severe rheumatoid arthritis and problems with: Walking, Self-care,

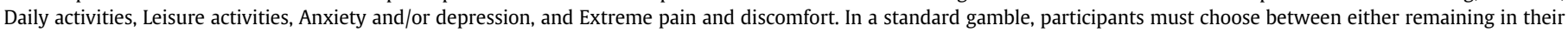

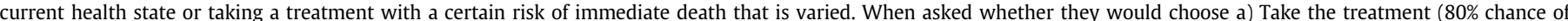

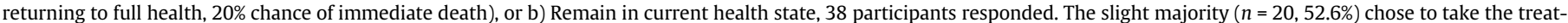
ment, rather than remain in their current health state. . 


\section{References}

[1] Hiligsmann M, Pinto D, Dennison E, Al-Daghri N, Beaudart C, et al. Patients' preferences for osteoarthritis treatment: the value of stated-preference studies. Aging Clin Exp Res 2019;31(1):1-3.

[2] Fraenkel L, Suter L, Cunningham CE, Hawker G. Understanding preferences for disease-modifying drugs in osteoarthritis. Arthritis Care Res (Hoboken) 2014;66 (8):1186-92.

[3] Fraenkel L, Bogardus Jr. ST, Concato J, Wittink DR. Treatment options in knee osteoarthritis: the patient's perspective. Arch Intern Med 2004;164(12):1299-304

[4] Lichtenstein S, Slovic P. The construction of preference. New York: Cambridge University Press; 2016.

[5] Ryan M, Gerard K. Using discrete choice experiments to value health care: current practice and future prospects. Appl Health Econ Policy Anal 2003(2):55-64

[6] O'Brien BJ, Elswood J, Calin A. Willingness to accept risk in the treatment of rheumatic disease. J Epidemiol Community Health 1990 Sep;44(3):249-52. doi: 10.1136/jech.44.3.249.

[7] OMERACT (Outcome measures in rheumatology). 2021 https://www.omeract.org.

[8] Tugwell P, Boers M, Brooks P, Simon L, Strand V, et al. OMERACT: an international initiative to improve outcome measurement in rheumatology. Trials 2007;8:38.

[9] Boers M, Beaton DE, Shea BJ, Maxwell LJ, Bartlett SJ, Bingham CO, et al. OMERACT filter 2.1: elaboration of the conceptual framework for outcome measurement in health intervention studies. J Rheumatol 2019 Aug 1;46(8):1021.

[10] The OMERACT handbook. 2019 https://omeracthandbook.org/handbook.

[11] Staniszewska S, Brett J, Mockford C, Barber R. The gripp checklist: strengthening the quality of patient and public involvement reporting in research. international journal of technology assessment in health care, 27. Cambridge University Press; 2011. p. 391-9.

[12] Fraenkel L, Nowell WB, Wiedmeyer C, Wei Z, Michaud K, Neogi T, Ramsey C, Broniatowski D. Development of a rheumatoid arthritis global outcome measure to enable comparisons of patient experiences across treatment arms in randomized clinical trials [abstract]. Arthritis Rheumatol 2018;70(suppl 10).

[13] Tong BC, Huber JC, Ascheim DD, Puskas JD, Ferguson Jr. TB, et al. Weighting composite endpoints in clinical trials: essential evidence for the heart team. Ann Thorac Surg 2012;94(6):1908-13.

[14] van Herwaarden N, van der Maas A, Minten MJ, van den Hoogen FH, Kievit W, et al. Disease activity guided dose reduction and withdrawal of adalimumab or etanercept compared with usual care in rheumatoid arthritis: open label, randomised controlled, non-inferiority trial. BMJ 2015;350:h1389.

[15] van Overbeeke E, Janssens R, Whichello C, Schölin Bywall K, Sharpe J, et al. Design, conduct, and use of patient preference studies in the medical product life cycle: a multi-method study. Front Pharmacol 2019;10:1395. doi: 10.3389/ fphar.2019.01395.

[16] Food and Drug Administration. Patient preference information - voluntary submission, review in premarket approval applications, humanitarian device exemption applications, and de novo requests, and inclusion in decision summaries and device labeling: guidance for industry, food and drug administration staff, and other stakeholders. 2016. https://www.fda.gov/AboutFDA/CentersOffices/OfficeofMedicalProductsandTobacco/CDRH/CDRHPatientEngagement/ucm 462830 . htm. Accessed Jan 2021. 